\title{
KAKO TRŽIŠTE RADA U SRBIJI UTIČE NA UPRAVLJANJE LJUDSKIM RESURSIMA
}

\section{THE WAY HOW LABOR MARKET IN SERBIA AFFECTS HUMAN RESOURCE MENAGEMENT}

\section{Dragan Vukomanović}

Fakultet za ekonomiju i inženjerski menadžment, Uiverzitet Novi Sad, Novi Sad, Srbija

\section{Dragana Vukomanović}

Pravni fakultet, Univerzitet Novi Sad, Novi Sad, Srbija

\section{Slavko Ivković}

Poslovni i pravni fakultet, “Union - Nikola Tesla” Univerzitet, Beograd, Srbija

OMESTE

JEL Category: E24, R23

\begin{abstract}
Apstrakt
Tržište rada je mesto susretanja ponude i tražnje za radom, koje ima svoj mehanizam koji funkcionište manje više sa uspehom u svim zemljama. Kako bi se na najbolji način podigla efikasnost na tržištu rada potrebno je, uz dobar menadžment, upravljati ljudskim resursima, tako što će se stvoriti adekvatni uslovi poslovanja, dinamika rada, zatim principi vrednovanja, adekvatan sistem komuniciranja među njima. U svakoj zemlji tržište rada zavisi od veličine ekonomije kao i ljudskih resursa. Osnovni resurs svake organizacije čine ljudi i njihove sposobnosti, kojima doprinose ostvarivanju organizacionih ciljeva. Tržišni uslovi privredjivanja posebno afirmišu kadrove, kao jedine resurse na globalnom nivou sa ulogom kreatora novih rešenja, stvaroaca novih vrednosti i upravljača procesa rada. Predmet ove studije su upravljanje ljudskim resursima na državnom nivou, stilovi upravljanja i pravilan izbor kadrovske politike Rezultati nedvosmisleno pokazuju da neadekvatno upravljanje direktno direktno utiče na motivaciju, zadovoljsvo i komunikaciju unutar organizacije, kao i na karakteristike radnog okruženja, a indirektno na produktivnost i profitabilnost kompanije.
\end{abstract}

Ključne reči: menadžment, ljudski resursi, srpsko tržište, modern tendencije, zaposlenost, menadžment tržišta rada.

\begin{tabular}{|c|c|}
\hline & Abstract \\
\hline $\begin{array}{l}\text { Adresa autora zaduženog za korespodenciju: } \\
\text { Dragan Vukomanović } \\
\text { 㛃 dragan.vukomanovic@gmail.com }\end{array}$ & $\begin{array}{l}\text { The labor market is the place to meet the supply } \\
\text { and demand for work, which has its own } \\
\text { mechanism that functions with less success in } \\
\text { all countries. In order to improve efficiency in the }\end{array}$ \\
\hline
\end{tabular}


labor market in the best way, it is necessary, with good management, to manage human resources, by creating adequate business conditions, working dynamics, then principles of evaluation, adequate communication system among them. In every country, the labor market depends on the size of the economy and the human resources. The core resources of each organization are people and their abilities, which contribute to the achievement of organizational goals. Market conditions of economy in particular affirm human resources as the only resources on the global level with the role of creators of new solutions, new values and process controllers. The subject of this study is the management of human resources at the state level, the management styles and the proper choice of personnel policy. The results clearly indicate that inadequate management directly affects the motivation, satisfaction and communication within the organization, as well as the characteristics of the work environment, and indirectly to productivity and profitability companies.

Keywords: management, human resources, Serbian market, modern tendencies, employment, unemployment, managment of the labor market

\section{UVOD}

Specifičnost tržišta rada proizilazi takođe iz činjenice na se na ovom tržištu "trguje" radnom snagom kao subjektivnim faktorom proizvodnje, na određeno vreme, međutim rad se samo iznajmljuje na to određeno vreme, jer je jasno da radnike ne možemo kupovati ili prodavati, što tržište rada čini drugačijim od tržišta kapitala i tržišta roba.

Ukoliko se na tržištu rada nastoji postići rast i razvoj, mora se obezbediti adekvatna kadrovska struktura i stvoriti uslovi za njeno efikasno korišćenje. Danas se ovaj proces naziva upravljanje ljudskim resursima, čiji menadžment ima ključnu ulogu u uspešnom organizaciji celokupnog procesa. Kako ljudi imaju odlučujuću ulogu na tržištu rada, moglo bi se reći da je investiranje u ljudski kapital mnogo bitnije nego u fizički kapital.

Reforma administracije u Srbiji je vrlo katuelna u poslenjih nekoliko godina, što je učinilo da upravljnje ljudksim resursima se prepozna kao nezaobilazna I veoma važna funckija u okviru javne uprave. $\mathrm{Na}$ centralnom nivou donošenjem Zakona o državnim službenicima iz 2005.godine kao I propratnih propisa, process upravljanja ljudskim resursima se odvijao I razvijao u okviru drzavne uprave. $\mathrm{Na}$ lokalnom nivou on je uveden tek Zakonom o zaposlenima u autonomnim pokrajinama i jedinicama lokalne samouorave, te se primenjuje od 01.12.2016. godine.

Tema rada odnosi se na upravljanje ljudskim resursima na tržištu rada u Srbiji gde se nastoji prikazati međusobna povezanost između ove dve kategorije.

\section{POJAM I FUNKCIONISANJE TRŽIŠTA RADA}

Teško je definisati tržište rada jer je ono veoma specifično. Specifičnost tržišta rada proizilazi najpre iz toga što ne postoji jedinstveno tržište rada, jer je ono podeljeno na nekoliko tržišta na kojima se formira ponuda i tražnja za određenom kategorijom rada.

Ponuda i tražnja na tržištu rada su kategorije koje je potrebno detalnije prikazati. Pa tako, ponuda na tržištu rada predstavlja količinu rada koju nude pojedinci u vidu individualnog rada svojim potencijalnim poslodavcima po određenoj ceni, tačnije najamnini, u određenom vremenskom period.

Sa druge strane tražnja na tržištu rada je uzvedena tražnja, jer je tražnja određenog preduzeća na tržištu rada za radnicima izvedena iz namera potencijalnih potrošača da kupe određen proizvod ili uslugu, a želja preduzeća da tu robu ili uslugu proizvede i proda.

Pojam koji je nerazdvojan od tržišta rada je pojam nezaposlenosti. Radić navodi da nezaposlenost pored inflacije predstvalja najveći problem sa kojim se suočava jedna država. Sa jedne strane, država gubi svu robu i usluge koji su potencijalni radnici mogli proizvesti, dok se sa druge strane suočava sa recesijom jer proizvedena dobra nema ko da kupi. (Radić, 2007, str. 39)

Stopa nezaposlenosti (U) izračunava se kada se u odnos stave sledeći parametri (Josifidis, 2008, str. 224):

$$
\mathrm{U}=\frac{\text { broj nezaposlenih }}{\text { zaposleni+nezaposleni }}
$$


Zaposleni i nezaposleni u jednoj državi zajedno čine radnu snagu. O ovoj temi opširnije će biti reči u tački broj 3 koja je vezana konkretno za Srbiju.

\section{UPRAVLJANJE RESURSIMA}

\subsection{Planiranje ljudskih resursa}

Da bismo mogli planirati ispunjenje strateških ciljeva organizacije, moramo planirati pravi broj zaposlenih, koji imaju željene kompetencije, znanja i potencijal za razvoj. Zbog toga je proces planiranja ljudskih resursa bitan proces, odnosno funkcija upravljanja ljudskim resursima. Strateško planiranje je određivanje ukupne organizacijske svrhe i načina kako ju postići. Planiranje je dalji korak u operacionalizaciji i konkretizaciji strategija. Preduslov ispravnog planiranja ljudskih resursa je usklađenost poslovnih planova i organizacije sa planovima ljudskih resursa. U praksi se, nažalost, često dešava da organizacije čitav proces koji netačno nazivaju i planiranjem ljudskih resursa, završe sa planom, odnosno jednom tabelom broja zaposlenih u godišnjem planu poslovanja. Razvojem poslovne funkcije upravljanja ljudskim resursima, vlasnici i menadžeri su postajali svjesniji da je zapravo taj deo planiranja suština samog poslovnog planiranja. Sposobnost organizacije, odnosno njenih zaposlenih da dostignu poslovne ciljeve je jedan od najvažnijih interesa menadžmenta, tako da planiranje ljudskih potencijala sve više dobija na važnosti. Svemu ovome moze doprineti aktivnija uloga drzave kroz programe u okviru nacionalne sluzbe za zaposljavanje.

$U$ poslednjih nekoliko godina, ali i danas, menadžment ljudskih resursa suočava se sa brojnim i dinamičkim promena u organizacijskoj sredini kao što su promene u tehnologiji, na tržištu rada, kulturnim različitostima, ali i sa ekonomskom krizom i njenim posledicama. Usledio je nagli razvoj tehnologije i tržišta, uslovio kraći životni period proizvoda, što dalje od zaposlenih zahteva nova tehnološka znanja i inovativnost.

Prena Vujić, pod menadžmentom ljudskih resursa podrazumeva se proces aktivnosti usmerenih na realizaciji organizacijskih ciljeva i to putem (Vujić, 2015, str. 39):

- obezbeđenja ljudskih resursa - znanja, sposobnosti, veština potrebnih organizaciji da ostvari poslovne ciljeve,
- osposobljavanja i angažovanja ljudi (obučavanje, razvoj, motivisanje, procena, nagrađivanje),

- menadžmenta promena, bilo u oblasti strukture zaposlenih ili organizacione strukture,

- administrativnih aktivnosti.

Često su obeležja upravljanja ljudskim resursima nesporni indikatori nivoa razvijenosti preduzeća $i$ njegovih internih karakteristika, koje sa druge strane emituju poruku zaposlenima šta se od njih očekuje u smislu (Đurović, 2008, str. 61):

- zaposleni je trošak - moramo ga smanjiti

- zaposleni je dinamički resurs - moramo ga aktivirati

U ovim porukama sadržana je i vizija i strategija i taktika, tj. politika ostvarivanja ciljeva preduzeća na duži rok.

Dakle, savremeno shvatanje upravljanja ljudskim resursima obuhvata sve povezane aktivnosti koje dovode do ostvarivanja postavljenih ciljeva u organizaciji. Zaposleni u preduzeću su najskuplji resurs. Upravljanje ljudskim resursima u preduzeću mora biti dugoročno i strateški planirano. Kriterijum uspešnosti preduzeća zavisi od maksimalne korisnosti zaposlenog kao najvažnijeg resursa.

Kadrovski menadžeri se sve više uključuju u razvoj strategije i politike organizacije. Jasno je da se kadrovski menadžment promenio i da nastavlja da se menja, svakako ne zbog toga što se sve češće koristi izraz menadžment ljudskih resursa. Međutim, mnogim kadrovskim praktičarima nedostaje formalno obrazovanje iz modernog menadžmenta ljudskim resursima. Broj kadrovskih poslova se dramatično povećao od polovine $X X$ veka, ali je stopa rasta obrazovnog nivoa profesionalaca na ovom području bila mnogo sporija. Gotovo svima koji se bave kadrovskim poslovima nedostaje formalno obrazovanje u svim aktivnostima koja obuhvataju problematiku upravljanje ljudskim resursima, kao što su primera radi, pitanje regrutovanja kadrova, njihove selekcije, ocenjivanja performansi, razvoj karijere i drugo.

Kroz proces upravljanja kadrovima preduzeće je u situaciji da sagledava uslove obezbeđivanja optimalne kadrovske strukture, kao i da uoči probleme koji se mogu javiti usled nesklada 
između kadrovskih materijalnih resursa. Činjenica da se ne može obezbediti optimalna struktura u svakom momentu, niti postići uvek sklad između ciljeva i mogućnosti preduzeća i aspiracija svih zaposlenih, ne treba da obeshrabri napore na području planiranja kadrova. (Todorović, Đuričin, \& Janošević, 2000, str. 584)

\subsection{Razvoj karijere}

Kada su u skladu sa organizacionim ciljevima, individualni ciljevi zaposlenih postaju pokretačka snaga organizacije. Sistematsko planiranje karijere je značajna podrška razvoju individualnih potencijala i predstavlja jedan od važnih aspekata strateškog upravljanja ljudskim resursima. Praćenjem, ocenjivanjem, raspoređivanjem, usmeravanjem i razvijanjem zaposlenih i njihovih potencijala, obezbjeđuje se optimalna iskorištenost njihovih znanja, veština i sposobnosti, a sve u svrhu ostvarivanja organizacionih i individualnih interesa i ciljeva. Danas je upravljanje karijerom zaposlenih od suštinskog i strateškog značaja za rast i razvoj preduzeća. Razvoj karijere zaposlenih bitan je za firmu, jer pravilno i racionalno upravlja svojim najvažnijim resursom, motivišući, jačajući pripadnost firmi i povećavajući produktivnost. Pomaže pri retenciji zaposlenih, ali poslodavcu jasno ukazuje na edukacijske potrebe i olakšava ciljani i rezultatima usmeren odabir vrsta i načina ulaganja u znanje i veštine radnika. Kako su promene na tržištu sve ubrzanije i češće, važno je i da lično postanemo, vrlo svesni koliko je važno usmjeravati i planirati lični razvoj i karijeru. Kada poslodavci preuzimaju sve manje odgovornosti, radnici moraju preuzeti na sebe odgovornost za svoj razvoj kako bi zadržali, ali i povećali svoje mogućnosti zapošljavanja. Razvoj karijere uključuje planiranje karijere, razvoj mogućih pravaca karijere, aktivnosti treninga i razvoja, promociju, formalne kadrovske politike, kriterijume promocije, procenu, savetovanje i podsticanje mentorskog rada. Planiranje i upravljanje karijerom podrazumijeva koordiniranu aktivnost menadžera, pojedinaca i službe za razvoj ljudskih resursa. Sistematično planiranje karijere je značajna podrška razvoju individualnih potencijala i predstavlja jedan od važnih aspekata strateškog upravljanja ljudskim resursima na nacionalnom nivou. Karijera treba da bude podjednako predmet pažnje pojedinca i organizacije u kojoj radi kao I drzave. U okviru sopstvenog razvoja i ostvarivanja ciljeva, a pomoću planiranja razvoja karijere zaposlenih, organizacija dovodi individualne razvojne ciljeve u funkciju organizacionih. Zadatak svih rukovodilaca je da kontinuirano prate $i$ procenjuju ljudske potencijale iz aspekta zahteva poslova i da u dogovoru sa pojedincima predlažu njihovu promociju.

$\mathrm{U}$ vreme brzih tehnoloških promena, i poslovnih promena generalno, ono što smo naučili $u$ školama i fakultetima davno je prevaziđeno znanje, čak i ono što smo naučili juče danas već nije aktuelno, pogotovo ako radimo u industrijama kao što je IT, na primer. Napredak tehnologije je jedan od ključnih razloga zbog kojeg organizacije moraju kontinuirano obrazovati zaposlene. Sve dinamičniji razvoj novih tehnologija, porast proizvodne, stvaralačke moći ljudskog rada, oličen u sve većoj količini materijalnih dobara i nastajanju novih ljudskih potreba, pored ostalog, doveo je do toga da formalni obrazovni sistem nije mogao potrebnom dinamikom da odgovori ne sve veće zahtjeve tehnološkog razvoja. Proces učenja se postepeno u sve većoj mjeri preseljava u proces rada, postajući njegov sastavni deo.Drzava bi pre svega trebala u obrazovni sistem uvesti drugaciji program kako bi se sve vise mladih pisle zavrsenih fakulteta osposobilo za rad.Generalno drzava moze da utice na upravljanje ljudskim resursima preko trzista rada ukoliko ceo obrazovni system isplanira u skladu sa potrebama I zahtevima trzista.Kroz strategiju planiranja uslovljenog zakonskim regulativama na nacionalnom nivou mogla bi se postici optimalna iskoriscenost radne snage.

\section{SAVREMENE UPRAVLJANJA \\ TENDENCIJE LJUDSKIM RESURSIMA NA TRŽIŠTU RADA U SRBIJI}

Srbija je zemlja koja još nije uspela da se koracima evropskih integracija pridruži Evropskoj Uniji, pa samim tim ni tržištu rada Evropske Unije. Za ovo postoje zagovornici za i protiv, ali činjenice su da postoji nekoliko tački gledišta koje prikazuju koristi od prijema, a one su (Buha Stevović, 2010, str. 214):

- $\quad$ siguran pristup ogromnom tržištu. Trgovinski režim postaje otvoren za njih, te novopridošle zemlje mogu da koriste dobrobit ekonomije obima, 
- migracije radne snage u ostale delove EU,

- poboljšava se njihova pozicija u međunarodnim ekonomskim odnosima, kao i pozicija u okviru UN, STO, MMF, Svetske banke,

- već uvedeni elementi pravne države, tržišne privrede, demokratije, još uvek nedovoljno učvršćeni i sigurni, ulaskom u EU dobiće dodatnu stabilnost,

- uspešne članice mogu postati kandidati za ulazak u monetamu uniju, a time se otvara mogućnost korišćenja svih prednosti koje monetarna unija pruža.

Tržište rada u Srbiji karakterišu velike fluktuacije ponude i tražnje za radnom snagom i visoka stopa nezaposlenosti, a to sve utiče na upravljanje ljudskim resursima u našoj zemlji.

Srbija je zemlja koju su zadesile dve velike tranzicije, najpre 90tih godina kada tržište rada u našoj zemlji gotovo da nije funkcionisalo. Za ovaj period je karakteristična duboka ekonomska i politička kriza, izolavanost zemlje pod uticajem međunarodnih sankcija, značajna dominacija društvenog sektora naspram privatnog, kao i veliki udeo "sivog" tržišta rada.

Zatim je usledila tranzicija nakon 2000. godine. Ovaj period brojnih političkih previranja karakteriše niža dinamika liberalizacije tržišta rada, međutim pokreće se pitanje promene radnog zakonodavstva. Nakon promena $u$ zakonima poput Zakona o radu, Zakona o zapošljavanju, Penzijskom i invalidskom osiguranju tržište rada postaje atraktivnije za strane investitore.

Institucija koja je nadležna za upravljanje ljudskim resursima na tržištu rada Srbije jeste Nacionalna služba za zapošljavanje. Filijale Nacionalne službe za zapošljavanje širom zemlje redovno organizuju obuke, na osnovu analize stanja i tokova na lokalnim tržištima rada. Cilj obuke je da se nezaposlenim osobama iz različitih kategorija omogući sticanje dodatnih znanja i veština, kroz teorijsko i praktično osposobljavanje, kako bi postali što konkurentniji na tržištu rada i povećali svoje šanse za zapošljavanje. Nacionalna služba za zapošljavanje od 22. novembra sprovodi „Anketu poslodavaca 2017“, u cilju kontinuiranog praćenja potreba tržišta rada. Ovogodišnja anketa je sedma zaredom i njome će biti obuhvaćeno oko
5.000 poslodavaca iz svih oblasti rada. (NSZ, 2017)

Prema podacima Republičkog zavoda za statistiku u trećem kvartalu 2017. godine ukupna stopa nezaposlenosti iznosila je $12.9 \%$, a poređenja radi u trećem kvartalu u 2016. godini ta stopa je iznosila 13,8\%. (RZS, 2018)

Srbiji predstoji težak zadatak da u narednom periodu ostvari konvergenciju sa Evropskom unijom tako što će više nego prepoloviti sadašnje dramatično zaostajanje u stopi zaposlenosti kao glavnom sintetičkom pokazatelju stanja na tržištu rada. Naime, razlika u ključnim pokazateljima tržišta rada između Srbije i Evropske unije, a pre svega u stopi zaposlenosti stanovništva radnog uzrasta, koja trenutno iznosi 18 procentnih poena, predstavlja jednu od najvećih suštinskih prepreka priključivanju Srbije Evropskoj uniji. Za konvergenciju prema ciljevima koje postavlja strategija „Evropa 2020“ biće neophodno ostvariti brži prosečan godišnji privredni rast od proseka $\mathrm{EU}, \mathrm{uz}$ istovremenu istu ili veću radnu intenzivnost rasta. (Stamenković, i drugi, 2010)

Najkrupniji problem koji su nastali zbog promene Zakona o radnim odnosima u okviru državnih organa su:

1. Rad u jedinicama lokalne samouorave

2. Sticanje zvanja

3. Zapošljavanja u jedinicama lokane samouprave

4. Zaštita prava zaposlenih

5. Zakon o radnim odnosima

6. Položaj načelnika gradske i opštinske uprave.

Navedeni razlozi su bili više nego dovoljni za donošenje novog zakonskog akta koji bi regulisao položaj zaposlenih na lokalnom nivou.

U novije vreme se otvara sve više radnih mesta što unapređuje tržište rada u Srbiji. Česte akvizicije dovode do novijih, modernih kompanija koje su u potrazi za dobro obučenim kadrovima, kojih tržište Republike Srbije ima dovoljno. Kadar je stručan, obučen i voljan da radi ukoliko se omoguće pristojna primanja i stabilnost poslovanja. Veoma je važno angažovati mlade ljude, izvršiti treninge i obuku kako bi bili spremni da odgovore velikim izazovima kako na domaćem tako i na stranom tržištu.

U poslenje vreme se sve više javlja potreba za obučenim kadrovima, zbog velike ekpanzije 
tržišta, a globalizacija dovela je do čestih pomeranja radnika na medjunarodna tržišta. Dobro obučen radnik sposoban je da obavlja isti posao na bilo kom svetskom tržištu.

U Srbiji često dolazi do takozvanih "odliva mozgova", jer obučen i spreman kadar će tražeći bolje uslove otići na neka bolja i razvijenija tržišta. Ovo je ujedno u Srbiji i najveći rizik koji postaje jedan od glavnih problema današnjice. Česta pomeranja radnika dovode i do većih troškova treninga i obuke.

\section{ZAKLJUČAK}

Zaključak je da tržište rada predstavlja tržište na kom ljudi izkazuju potrebu da rade, i nude svoju radnu snagu, zatim svoje stručno znanje, stečeno radno iskustvo, svoje veštine i kompetencije. Ovako prikazanu radnu snagu kupuju poslodavci u određenom vremenu i obimu, a po određenoj ceni, i odnosi se na broj radnika koji će zaposliti.

Sveukupno gledano, planirani rast i razvoja tržišta rada treba da bude prožet nastojanjima da se obezbedi adekvatna kadrovska struktura, da se stvore uslovi za njeno korišćenje i da se njome uspešno rukovodi. Kroz proces upravljanja ljudskim resursima svako preduzeće, ali i država uopšteno, je u mogućnosti da sagleda uslove obezbeđivanja odgovarajuće kadrovske strukture, ali i da ujedno uoči sve problem koji se mogu javiti u budućnosti, posebno pitanja nezaposlenosti.

Zemlje u kojima je nivo regulacije tržišta rada na višem nivou, zaposlenost je manja ili obratno. Ukoliko postoje stroge zakonske regulative po pitanjima zarada zaposlenih, primanja i otpustanja, usporava se tržište rada, što dalje, radnu snagu čini manje pokretljivom, a privredu neefikasnijom. Za upravljanje ljudskim resursima povoljnim za radnike veoma je bitna zakonodavna zaštita zemlje, koja obuhvata jasne pravne norme koje ruguliše ova pitanja.

U Srbiji nezaposlenost predstavlja glavni kamen spoticanja za funkcionisanje tržišta rada, jer određen deo radno sposobnog stanovništa nije u mogućnosti da se zaposli u skladu sa svojim kompetencijama. Sa druge strane, u Srbiji postoji izražena regionalna nejednakost, visok udeo javnog sektora naspram privatnog, što koči uspešnu tranziciju kod nas. Međutim, nakon velikih i teških šokova koje su se dešavale na tržištu rada Srbije, ipak nam predstoji svetli period jer postoji volja države, ali i jasna vizija na koji način uspostaviti jasnu koordinaciju između strategija zapošljavanja, obrazovanja i naučnotehnološkog razvoja, u cilju poboljšanja uslova na tržištu rada.

\section{CITIRANA DELA}

Buha Stevović, J. (2010). Evropske integracije. Subotica: Ekonomski fakultet.

Đurović, M. (2008). Strategija internog marketinga u upravljanju ljudskim resursima. Beograd: Telekom Srbija.

Josifidis, K. (2008). Makroekonomija. Novi Sad: Futura publikacije.

NSZ. (2017, dec). Anketa poslodavaca 2017. Preuzeto sa Nacionalna služba za zapošljavanje: http://www.nsz.gov.rs/live/digitalAssets/9/9690_anketa_poslodavaca_2017._godine.pdf

Radić, J. (2007). Ekonomija rada i socijalna politika Evropske Unije. Subotica: Ekonomski fakultet.

RZS. (2018, april). Aktuelni indikatori - Kretanje stope zaposlenosti/nezaposlenosti stanovništva starosti 15+. Preuzeto sa Republički zavod za statistiku: http://www.stat.gov.rs/

Stamenković, S., Kovačević, M., Vučković, V., Jakopin, E., Bogdanov, N., Zdravković, M., . . Arsić, M. (2010). Postkrizni model ekonomskog rasta i razvoja Srbije 2011-2020. Beograd: USAID i FREN.

Todorović, J., Đuričin, D., \& Janošević, S. (2000). Strategijski menadžment. Beograd: Institut za tržišna istraživanja.

Vujić, D. (2015). Kompetencije za rad i rukovođenje. Beograd: Centar za primenjenu psihologiju. 
Datum prve prijave:

Datum prijema korigovanog članka:

Datum prihvatanja članka:
12.03.2018

26.07.2018.

05.09.2018.

Kako citirati ovaj rad? / How to cite this article?

Style - APA Sixth Edition:

Vukomanović, D., Vukomanović, D., \& Ivković, S. (2018, 10 15). Kako tržište rada u Srbiji utiče na upravljanje ljudskim resursima. (Z. Čekerevac, Ur.) FBIM Transactions, 6(2), 188-194. doi:10.12709/fbim.06.06.02.19

Style - Chicago Sixteenth Edition:

Vukomanović, Dragan, Dragana Vukomanović, i Slavko Ivković. 2018. „Kako tržište rada u Srbiji utiče na upravljanje ljudskim resursima." Urednik Zoran Čekerevac. FBIM Transactions (MESTE) 6 (2): 188-194. doi:10.12709/fbim.06.06.02.19.

Style - GOST Name Sort:

Vukomanović Dragan, Vukomanović Dragana i Ivković Slavko Kako tržište rada u Srbiji utiče na upravljanje ljudskim resursima [Časopis] // FBIM Transactions / ur. Čekerevac Zoran. - Beograd: MESTE, 1510 2018. - 2 : T. 6. - str. 188-194.

Style - Harvard Anglia:

Vukomanović, D., Vukomanović, D. \& Ivković, S., 2018. Kako tržište rada u Srbiji utiče na upravljanje ljudskim resursima. FBIM Transactions, 15 10, 6(2), pp. 188-194.

Style - ISO 690 Numerical Reference:

Kako tržište rada u Srbiji utiče na upravljanje ljudskim resursima. Vukomanović, Dragan, Vukomanović, Dragana i Ivković, Slavko. [ur.] Zoran Čekerevac. 2, Beograd : MESTE, 15102018 , FBIM Transactions, T. 6, str. 188-194. 